Historic, Archive Document

Do not assume content reflects current scientific knowledge, policies, or practices. 



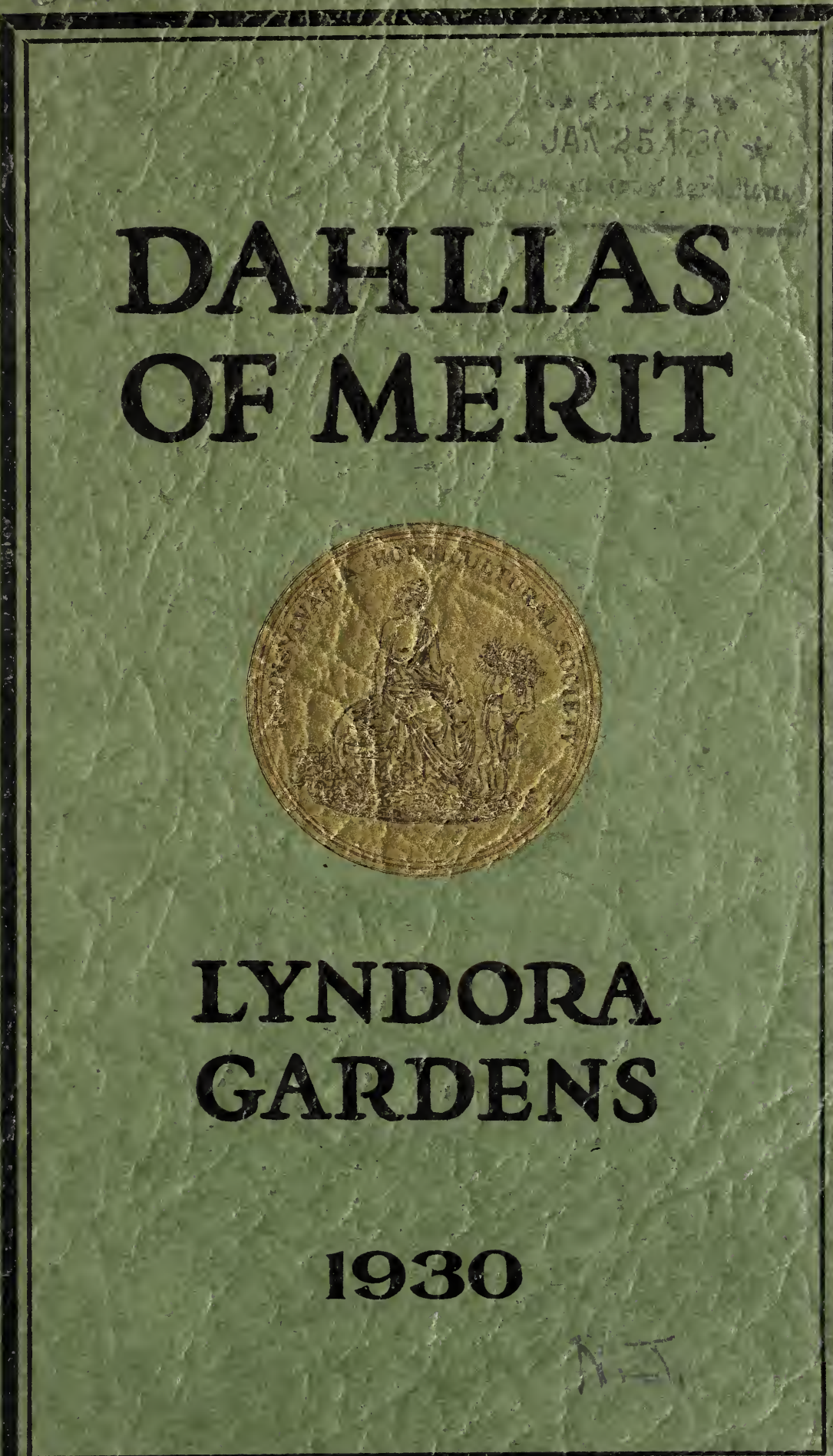




\section{DAHLIAS OF MERIT}

\section{F O R E W O R D}

Realizing that a large list of Dahlias is confusing to a buyer, we are offering in the following list only varieties which we have found reliable and satisfactory.

If you are undecided regarding the varieties to buy this year, we shall be glad to assist by supplying any information we may possess regarding the variety in question.

We wish to call your attention to three Lyndora Dahlias offered this year for the first time. They have been excellent performers with us and while we realize that Dahlias differ in their cultural and climatic requirements, we believe these varieties will "make good" if given a fair chance.

\section{LYNDORA GARDENS}

416 Chester Ave.,

Moorestown, N. J.

\section{G E N E R A L I F OR M A I O N}

TUBERS AND PLANTS-We offer field-grown tubers and in the cases of some varieties, green plants in pots. We consider plants as satisfactory as tubers if planted promptly upon arrival and not allowed to become dry.

TIME OF SHIPMENT-Tubers, March 1st to June 1st; Plants, May 15 th to June 15th, unless otherwise noted. Shipments before March 1st at buyer's risk.

SUBSTITUTION-We do not substitute unless directed to do so.

TERMS-Cash before shipment. If full payment is enclosed with order a discount of $5 \%$ may be deducted from retail orders. All retail orders shipped prepaid.

WE GUARANTEE-All stock to be true to name and from strong, healthy, field-grown stock. Also in good growing condition when delivered.

ORDER EARLY-To avoid disappointment as stock of some of the most desirable new varieties will not be sufficient to fill all orders.

ADDRESS PLAINLY-Please write name and full address plainly. 


\section{CULTURAL NOTES}

Dahlias will grow to perfection in almost any soil provided proper care is given to the method of planting, fertilizing, cultivating and watering.

Put out tubers or plants from June 1st to July 1st. Those planted early will usually produce the largest tubers.

Prepare soil by spading or plowing 12 to 18 inches deep. Work into the soil well decomposed stable manure or vegetable matter, such as partly decomposed leaves, lawn trimmings, etc. Scatter 1/4 pound of Ground Bone about each hill at planting time and $1 / 2$ pound per plant applied about August 1st. As a substitute for Bone, good potato fertilizer or sheep manure may be used to advantage.

Plants are usually set 3 by 4 feet. Strong growing varieties, if well fed, may need more room. Thorough and frequent cultivations during the first two months after planting, with moderate side dressings and very shallow cultivation and mulching the remainder of the season, is recommended. As a general practice water only during very dry weather, when it should be very thoroughly done. Little watering will be necessary if soil has been spaded deeply and contains a liberal amount of humus and is well mulched after August 1st.

To produce large blooms begin training plants when small by leaving from four to six of the strongest laterals as low down on the main stem as possible. Remove all side shoots and buds excepting the main or terminal bud on each of the laterals.

During the past season, Leaf Hoppers and Thrips were quite troublesome in some sections of the country, checking the growth and causing stunted plants. The best known remedy to prevent injury by these insects is spraying or dusting with nicotine solution or dust. In the case of Thrips, which are usually found in the terminal growths, the solution or dust should be applied from above, especially at the growing points; while for Leaf Hoppers, the application should be made to the lower side of the leaves. We had splendid control of Leaf Hoppers last season by treating them as follows: Soon after plants were put out in the field a thorough application of nicotine dust (not tobacco dust) was applied to the under side of the leaves and this operation repeated twice a week until plants were two or three feet in height. After this stage, although the Hoppers were present, the plants apparently were unaffected. Some varieties show the effects of this insect much more than others. Thin leafed varieties appear to be especially susceptible. 


\section{Lyndora 1930 Introductions}

GOLD IMPERIAL (D)

TUBERS PLANTS

$\$ 10.00 \quad \$ 5.00$

A very deep and perfect formed flower with high, well furnished center. Plant vigorous, low growing, with blooms carried well above the foliage on good stems. Color rich brilliant gold with just a tint of lavender on reverse. Not extremely large but of good exhibition size and should be popular for show and home decoration on account of its charming form and color. Won Gold Medal at 1929 Camden Dahlia Society as the best undisseminated seedling in a very strong class.

GOV. MORGAN F. LARSON (D) (Stock limited, prices net) 10.00

Blooms very large with good center and form. Color clear golden yellow with slight apricot blush on reverse, that adds richness in tone especially under artificial light. Growth medium to tall, stems good. Won Governor's Cup at 1929 New Jersey State Show at Trenton as most worthy undisseminated Dahlia. Also won Cup as best yellow, cream, or buff at Camden Show, 1929.

A very attractive well formed Dahlia of large exhibition size with good center and stem. Color is clear golden yellow tinted apricot in a deep, massive, graceful flower. Plant tall and vigorous with large thick leaves. This Dahlia should become a favorite for garden, show or house decoration. Winner of the Silver Medal at the Pennsylvania Horticultural Society 1929 Show as best established seedling. 


\section{G E N E R A L L I S T}

\section{AMBASSADOR (Cac) (Broomall)}

Golden yellow and salmon pink, very large with full center, strong grower, perfect stem. It has been a consistent winner with us wherever shown.

AVALON (D) (Broomall)

Light yellow, blooms very large and heavy. Growth strong.

\section{AZTEC GLORY (D) (Broomal!)}

Color a bright, attractive lemon yellow. Size very large, carried on good stems, excellent form.

BARBARA REDFERN (D) (Redfern)

Blooms large, well formed, with good centers. Stem strong, slightly bent. Plant tall and vigorous. Color gold, overlaid with blends of copper and old rose.

BARBARA WEAR (D) (Seal)

A 1927 medal winner from California. Color soft pinkish lavender. Blooms large, of good form, carried on excellent stems.

BRUNO (D) (Lyndora 1927)

This was one of the most showy Dahlias in our garden the past season. The large vigorous plants were full of blooms from early until late. Color rose tinted red. Awarded Certificate of Merit at American Dahlia Society Trial Gardens, at Storrs, Conn.

\section{CHARLOTTE LAFRENZ (D) (Seal)}

A large attractive new Dahlia. Color gold shading to apricot in outer petals. Form and center good. Growth and stems strong.

CHEMAR'S PURITY (D) (Chemar)

Color white with greenish tint in center when opening. Size large, centers and stems good.

CITY OF TRENTON (D) (Prentice, Fisher \& Masson) Color light orange salmon with reddish reverse. Blooms large and well formed on good stems.

A very striking Dahlia both in form and color. Much admired at the Camden, New Jersey (State Show) where it won as best specimen bloom and again at Philadelphia where it was awarded a Silver Medal as best seedling. Also awarded Certificate of Merit at the New Jersey State Trial Grounds, where it scored 87. Color is a rich, deep salmon bronze of one shade. Clean up-right grower of excellent habits with perfect stems.

CONQUISTADOR (H. C.) (Ballay)

Soft creamy yellow shading to pink at base of petals. Blooms large and well formed. Bushes tall and vigorous, stems long and strong. A large exhibition Dahlia with unusual keeping qualities. 
Color capucine yellow shading to grenadine red. Blooms large, well formed, with good centers held erect on fine stems. Growth very strong. One of the best of the new Dahlias.

DORIS CANNEY (D) (Seal)

A large well formed Dahlia of very pleasing color of golden apricot. Growth, stems and centers satisfactory.

DR. JOHN H. CARMAN (D) (Dixon)

A large, deep, broad petaled tyrian rose flower on a very strong, stiff stem. Growth vigorous. Certificate A. D. S., 1928.

EAGLE ROCK BEAUTY (D) (Broomall)

Large, well formed flowers on medium stems. Color pink and cream with amber suffusion. Plant of medium height, stem inclined to be soft if forced; growth variable.

EAGLE ROCK JEWEL (H.C.) (Broomall)

Cream overlaid with shell pink. Large blooms on strong stems, growth satisfactory.

EASTERN STAR (D) (Maytrott)

Saffron yellow with old gold shadings, medium to large, growth strong.

EDNA FERBER (H.C.) (F. \& M.)

Size very large with medium to good stems. Color coral shading to old gold at base of petals. Petals long and wavy.

ELEANOR VANDERVEER (D) (Seal)

Rose pink, very large with excellent stems. A strong grower and free bloomer.

ELITE GLORY (D) (Kennedy)

Red, mammoth size, very heavy stems, sturdy growth.

ELIZA LONDON SHEPARD (D) (Peacock) 1930 introduction

A large well formed Dahlia of attractive color, gold with apricot shadings. Bushes strong and free blooming, stems strong.

ELKRIDGE (D) (Griffiths)

Size medium to large on good stems. Petals thick and waxy, having good keeping qualities.

EMMA MARIE (H.C.) (Maytrott)

Color bright pink with white center. Size medium to large on good stems.

FLAME LICK (D) (Murphy)

Blooms large of good form carried on stiff stems. Plant of medium height. Color brilliant red.

FORT MONMOUTH (H.C.) (Kemp)

Blooms very large and well formed, carried on long, stiff stems high above a strong bush. Color rich crimson maroon. 


\section{FORT WASHINGTON (D) (Reinfleisch)}

A very tall, strong grower producing extra large blooms with good centers carried on long, strong stems.

GALLI-CURCI (D) (Lyndora 1928)

Strong semi-dwarf grower. Blooms large, unusually deep, carried facing on long sturdy stems. Center unusually high and well formed. Petals long, pointed and wavy. Color brilliant salmon orange with gold suffusion and an unusual amount of gold sheen or lustre. Awarded Certificate of Merit at Philadelphia in 1926 and again in 1927. At the 1927 New Jersey State Show at Atlantic City it was selected by Madame Galli-Curci to bear her name. Also won silver trophy at this Show. At Camden, 1927, Show, it was awarded a gold medal for best undisseminated seedling. Received Certificate of Merit at New Jersey State Trial Grounds.

GERTRUDE EDERLE (H.C.) (Bessie Boston)

Color creamy yellow. Blooms medium to large on good stems. Petals long and straight.

GRACE RICORDS (D) (Maytrott)

Blooms medium to large with many petals well placed, giving unusual depth. Color white with lavender blush at tips. Growth and stems good.

GRANDOLA (D) (BroomalI)

Brilliant orange. Size large. Form, center and stem good. Growth excellent.

HARRY MAYER (D) (Seltsam-Reed)

A very sturdy grower of semi-dwarf habit. Blooms very large, well formed with good centers carried on strong stems. Color pale rosolane purple.

HARRY SHELDON, JR. (D) (Murphy)

Outer petals bright lavender pink, center creamy white. Large, good form, medium stem.

IDA PERKINS (D) (Perkins)

A large, well formed clear white decorative; growth, stem and centers satisfactory. Awarded medal at Boston, 1927.

JACK O'LANTERN (D) (Reed)

Bloom large. Color bright orange red shading to dark Spanish red near center with center petals tipped with gold. Stems and growth satisfactory.

JANE COWL (D) (Downs)

Deep massive blooms of bronzy buff and old gold, blending darker toward the perfect center. Broad petals, with just enough twist to add the refinement so often lacking in the largest Dahlias. A stem of unusual strength holds this giant decorative over a bush of ideal growth, while the foliage is the thick leathery kind that insects seldom bother. Awarded first prize for undisseminated seedling and the Garden and Home Builder sweepstake medals at New York. Awarded Certificate of Merit at Storrs Trial Gardens, 1927. 
JEAN HARE (H.C.) (Fisher \& Masson)

Color yellow shaded apricot buff. Blooms med-

ium in size on good stems. Growth vigorous.

JERSEY'S BEACON (D) (Waite)

Chinese scarlet with paler reverse, very large, stem good, growth vigorous.

JERSEY'S BEAUTY (D) (Waite)

Soft clear pink, medium to large, excellent stem,

free bloomer and good keeper. Very popular.

JERSEY'S EMPRESS (H.C.) (Waite)

Purplish maroon, wavy petals, very large, stems medium to good, growth strong. Does not fade or burn.

JERSEY'S GLORY (D) (Waite) (1929 introduction)

Color a blend of orange and yellow. Blooms large and well formed on long, strong stems. Growth vigorous.

JERSEY'S IDEAL (D) (Waite)

Dark lavender pink, very large with good form and center, free blooming, fine stems, strong grower.

JERSEY'S JEWEL (D) (Waite)

Color light lavender, large, form loose and attractive, stems good, growth variable.

JERSEY'S MAMMOTH (D) (Waite)

Burnt orange, extra large (well grown flowers measure 12 to 14 inches in diameter). Growth strong, making tall plants. Stem weak.

JESSIE K. PRESCOTT (D) (Boston)

Orange brown tinted cream, large; form, stem and growth good.

JOVE (D) (Ballay)

A very large bronze pink from California. Growth, stem and center satisfactory.

KATHLEEN NORRIS (D) (Klein-F. \& M.) This outstanding 1929 Dahlia has won many prizes in the largest Eastern shows. Color soft, attractive rose pink. Blooms very large with good depth and form. Stems ideal. Highly recommended for exhibition. 
KING MIDAS (D) (Peacock)

A 1929 introduction of unusual merit resembling

Aztec Glory. Blooms very large, of deep golden yellow. Growth, stem, center and form desirable.

LADY LYNDORA (D) (Lyndora 1927)

A charming new color combination, being a blend of pink and white. Every visitor at our gardens during the past season was tremendously impressed with the color of Lady Lyndora. Size, large of distinct decorative type. A semi-dwarf grower and free bloomer. Needs heavy thinning and disbudding. Won Gold medal as best undisseminated seedling at Camden, 1926 (Dahlia Society of New Jersey Show). Certificate at New Jersey Trial Grounds.

LA RODA (D) (Broomall)

Silver rose pink. Large, well formed flowers on good stems. Centers high and full, growth satisfactory.

\section{LYNDORA (D) (Lyndora)}

Medium yellow with suffusion of amaranth pink on the reverse, large; form ideal, having long wavy petals which show just enough of the pink in reverse to brighten and illuminate the entire flower; stem good, growth strong, producing tall robust bushes. Won Silver Medal, (highest honors) for seedling at Philadelphia, 1925, and Gold Medal at New Jersey State Show, 1925. Awarded Certificates of Merit at both American Dahlia Society and New Jersey Trial Grounds in 1925.

MARGARET MASSON (D) (Fisher \& Masson)

Silvery lavender pink, very large, full form, excellent stems, strong grower.

MARGARET W. WILSON (D) (Fisher \& Masson) Plants dwarf, strong growing and free blooming, blooms very large with good stems, face of petals creamy white, reverse pink.

MARION BROOMALL (H.C.) (Broomall)

Plants tall and vigorous. Blooms very large with excellent centers. Petals very long and narrow. Color a very attractive two tone combination of pink and white. Stems excellent. A bloom of this variety exhibited by us at Camden, 1927, won best bloom in the Court of Honor.

MARLEAU (D) (Broomall-Success)

Pinard yellow, shaded capucine orange, general effect being salmon buff. Large flowers on strong stems. 
Growth very strong, blooms unusually large and deep. Stems long and strong, color golden yellow with bronze suffusion near the center. An outstanding novelty of 1926 and winner of many prizes.

MAY TROWER (D) (Seal)

Color gold, shaded apricot, blooms large, deep and of irregular and unusual form. Stems long and rigid.

MISS CALIFORNIA (D) (Pelicano)

Bushes tall and vigorous, blooms large, form medium, stems long and strong, color oriental fuchsia.

MISS SAN FRANCISCO (D) (Pelicano)

Color orchid and deep rose. Blooms large with good centers and stems. Growth good.

MORDELLA (D) (King)

Apricot buff, large, good stem, plant very tall and strong.

MR. E. LEEDHAM (D) (Bessie Boston)

Orange scarlet. Blooms large with good centers and stems. Color does not fade or burn. Growth strong. The best of its color we have grown.

MRS. ALFRED B. SEAL (D) (Seal)

An outstanding 1929 introduction and one of the best in our trial garden the past season. Plants tall and vigorous, producing very large, deep, full centered blooms on perfect stems. Color soft, attractive old rose.

MRS. ELEANOR MARTIN (D) (Pelicano)

Mulberry red, very large, good form, perfect stem, good grower, very satisfactory for exhibition or cutting.

MRS. ELIZABETH GLENDINNING (D) (Lyndora 1926) Color decided oriental, being a pleasing blend of orange, tyrian rose and amaranth pink, size large, form good, full centered, stem excellent, growth satisfactory.

MY MARYLAND (H.C.) (Downs)

A beautiful hybrid-cactus of unusually delicate pink with the faintest suggestion of lavender. The petals twist in an attractive manner. The flower is large, carried on an excellent stem, plant tall of medium vigor.

NANCY SUE LANG (D) (Broomall)

Very large well formed flowers on excellent stems. Color dull red tipped with gold. Considered much better than Mrs. E. L. Lindsay. Plants semi-dwarf, strong growing. Requires good culture.

Lilac and lavender pink, large, excellent stem, dwarf, free bloomer. 
PRIDE OF STRATFORD (D) (M. \& S.)

Color, face deep orange, reverse madder brown, center petals slightly quilled. Blooms very large on good stems.

REGAL (D) (Bessie Boston)

A very large, well formed decorative of a pleasing combination of bronze and dull old rose. Stems centers and growth satisfactory. One of the best 1928 introductions.

ROBERT E. LEE (H. C.) (Peacock)

A 1930 introduction. Color bright crimson red that does not fade or burn. Long strong stems; form unusual and attractive.

ROMAN EAGLE (D) (Fisher \& Masson)

Blooms large, sometimes showing centers, color burnished copper, stems strong.

ROSENA (D) (Lyndora 1927)

This is a very large, well formed decorative, 9 to 10 inches in diameter when disbudded. Color spiral pink. Stem growth and blooming characters excellent. Received Certificate of Merit at the New Jersey State Society Trial Grounds.

SAGAMORE (D) (Badetty)

Light apricot buff, medium size, good stem. A good grower and excellent bloomer. Flowers are highly prized for their color and keeping qualities.

SANHICAN'S MAGNATE (D) (Fisher \& Masson)

Dwarf strong growing, blooms very large on good stems, color dull lavender face with claret reverse, free bloomer.

SANTA ANNA (H.C.) (Pelicano)

Large, of excellent form. Petals long and curling. Color salmon rose suffused with gold. Stems and growth satisfactory. Very pleasing in form and color.

SEAL'S CALIFORNIAN (D) (Seal)

Blooms of this variety are large on very strong stems. Plants vigorous with heavy foliage. Color a bright golden yellow suffused with pink.

\section{SHOE CITY (D) (Carver)}

Large, deep, well formed flowers of soft buff apricot. Bushes semi-dwarf with thick heavy foliage.

Stems strong and upright. 
Blooms very large, petals long and tightly rolled. Color white with soft lavender center. Stems medium, plant tall and vigorous.

SISKIYOU (H.C.) (BroomalI)

Lavender pink, extremely large, strong stem. Has often won largest bloom in the shows.

SNOW BOY (H.C.) (Lyndora 1927)

A pure white with excellent formation. Plant strong of medium height and an unusually free bloomer, petals well rolled, center high and well formed. Stem strong, carrying blooms well above the foliage. We recommend this variety believing it to be outstanding as a white hybridcactus. Especially valuable for commercial use or home decoration. Size of blooms 7 inches. Awarded Certificate of Merit at the New Jersey Trial Grounds in 1926.

SOLE MIO (D)

Strong, semi-dwarf grower, blooms very large and well formed borne on excellent stems. Color light yellow.

STARLIGHT (H.C.) (Bessie Boston)

Color pure unshaded gold. Blooms large and well formed, carried on fine stems.

THE BANDIT (D) (Reed)

Growth upright, slender, blooms medium to large, rather thin, petals wavy, color spectrum red, reverse of old gold, stems good. Growth variable.

THE LEMONADE (D) (Ward)

Color pale lemon yellow. Blooms large to very large, carried on excellent stems. Form full with good depth and center, vigorous grower. Excellent for exhibition, the best of its color.

THE WORLD (D) (Maytrott)

Blooms large and well formed. Petals unusually heavy and long keeping. Color rich deep rosy magenta with silver shadings. Growth and stem ideal.

TRENTONIAN (D) (Fisher \& Masson)

Brown copper bronze, very large, excellent stem, growth strong and tall. 
UNCLE REMUS (D) (BroomalI)

Strong semi-dwarf grower, blooms large with full centers. Stems strong, plant vigorous. Color, rosy purple.

WALDHEIM SUNSHINE (D) (Peacock)

Color, a true deep yellow with darker shading that improves under artificial light. A rich golden suffusion brightens its full high center. Form very attractive, having long, wavy petals. Size extra large. Said by originator to grow 12 inches in diameter. Stems long and sturdy holding flowers facing. Free bloomer and strong grower. Centers hold until frost.

WATCHUNG SUNRISE (D) (Smith)

Strong healthy plant carrying its large, well formed blooms of gold with pink suffusion, far above the foliage. A profuse and early bloomer. Stems unusually good. Centers high and well formed.

YANKEE KING (D) (Wood)

A 1928 introduction from N. E. Color coppery rose and old gold. Blooms large and well formed on very long rigid stems. Bushes large and vigorous. Won A. D. S. Certificate of Merit, 1927.

YELLOW BEAUTY (D) (Wood)

A long stemmed yellow commercial Dahlia that can be grown to exhibition size. Considered by Mr. W. H. Waite to be a good running mate for Jersey's Beauty.

ZANTE (H.C.) (Bessie Boston)

Gold suffused with apricot pink, large, excellent stem. Growth good. 


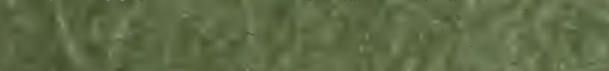

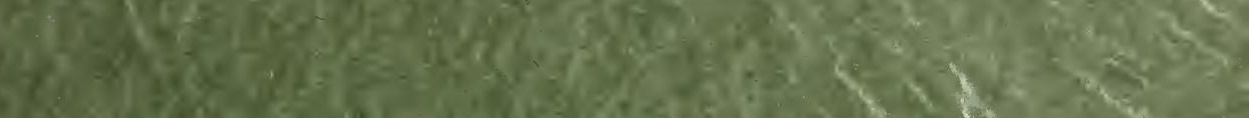
2.

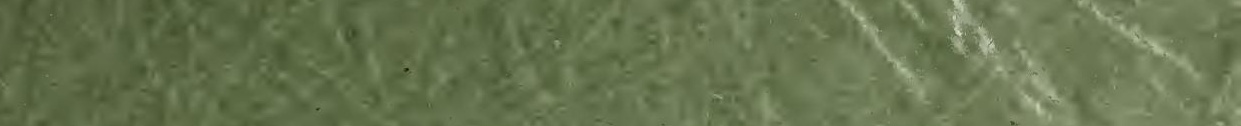

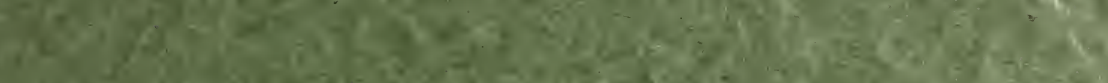

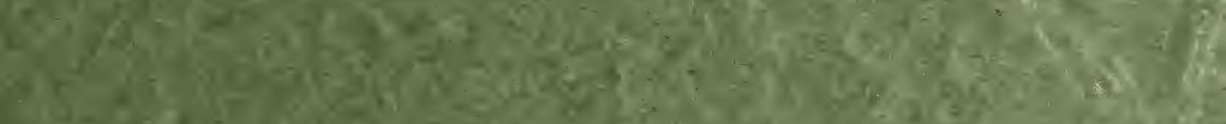

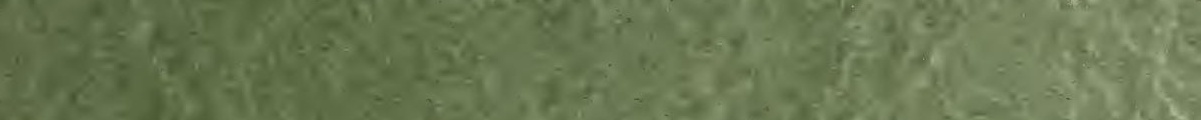

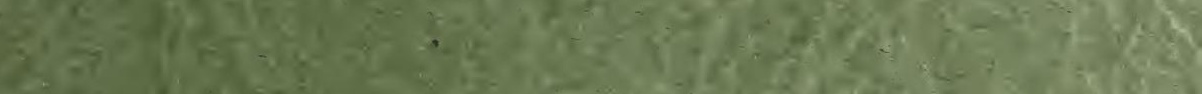

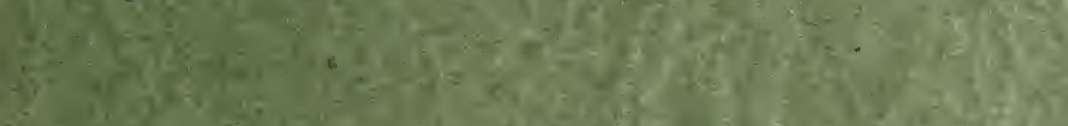

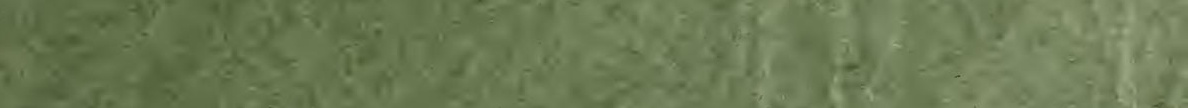

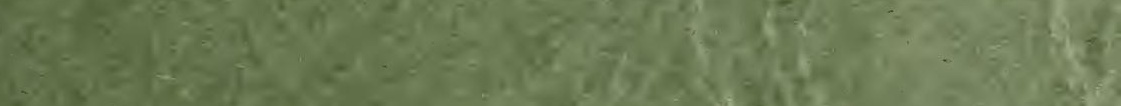

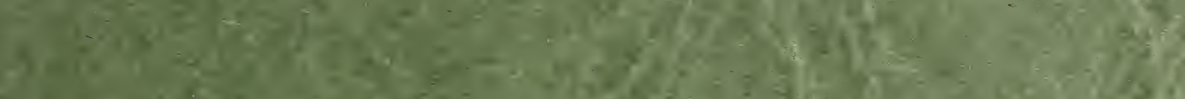

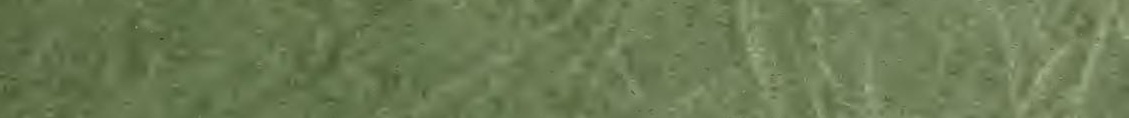

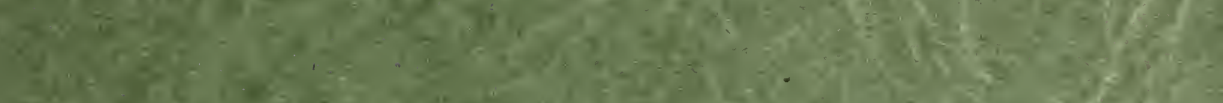

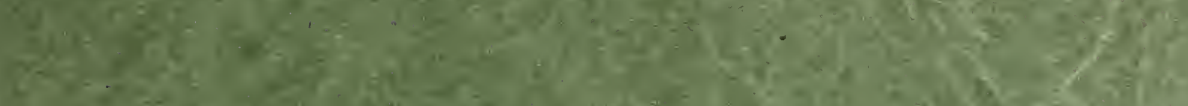

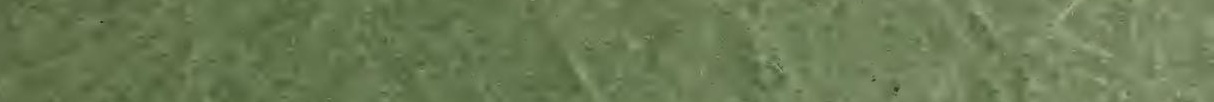

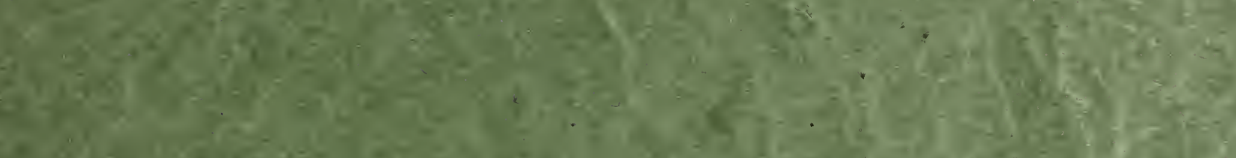

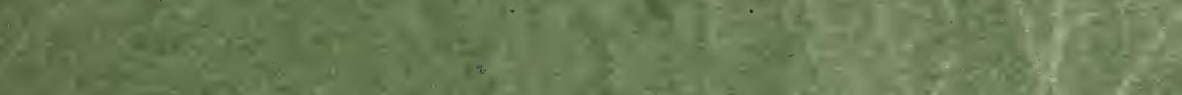

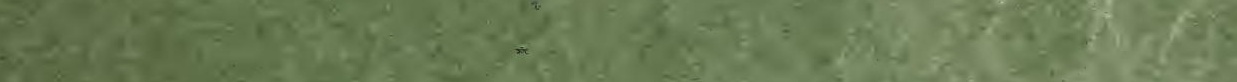

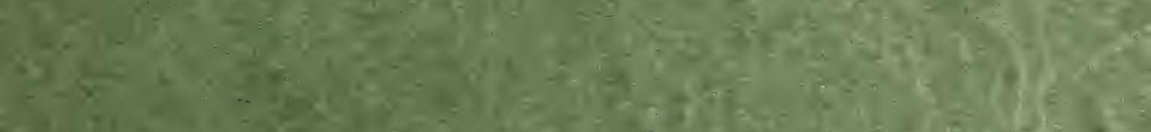

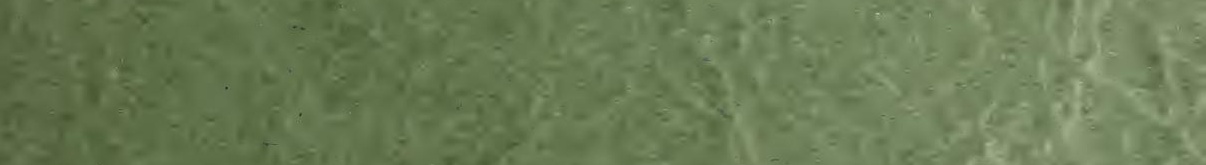

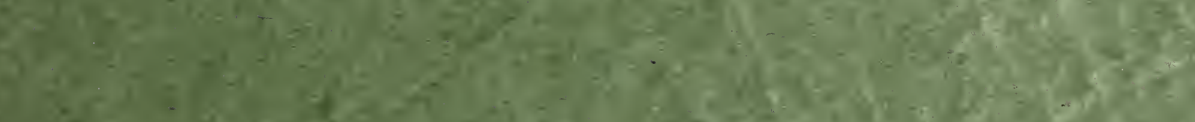

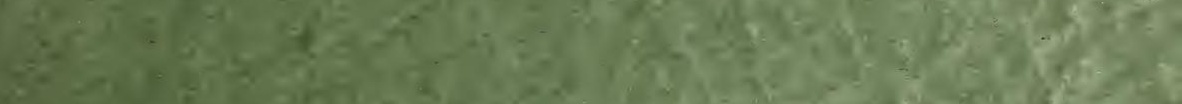

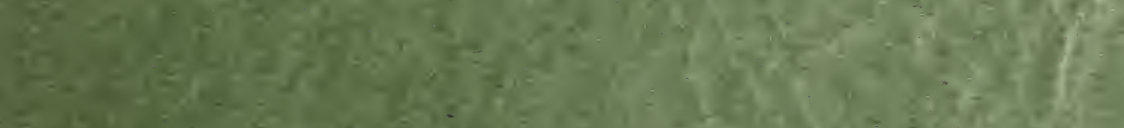

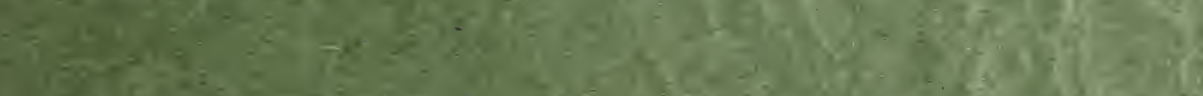

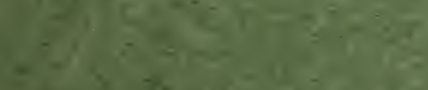

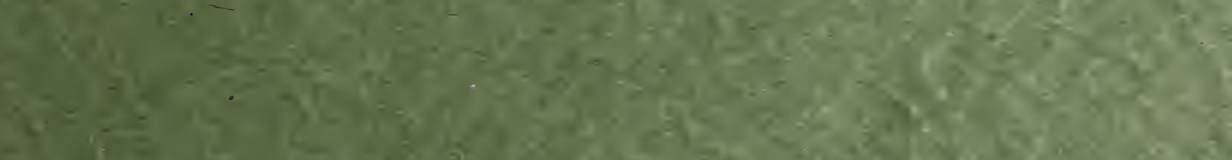

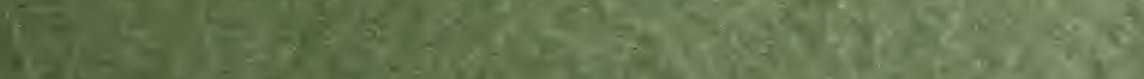

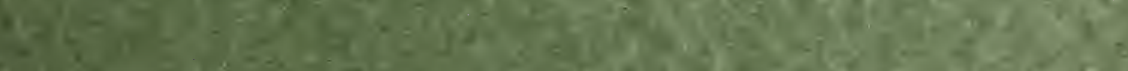

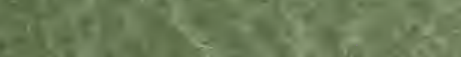




\section{9}

(3)

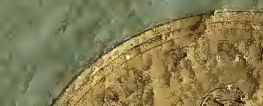

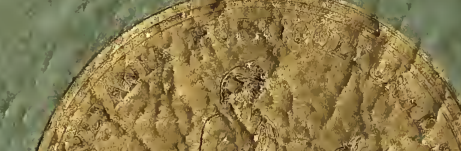

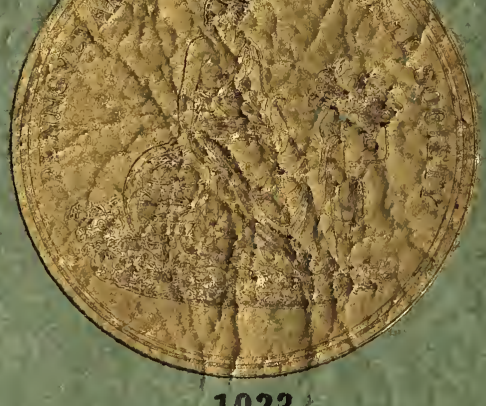

1923

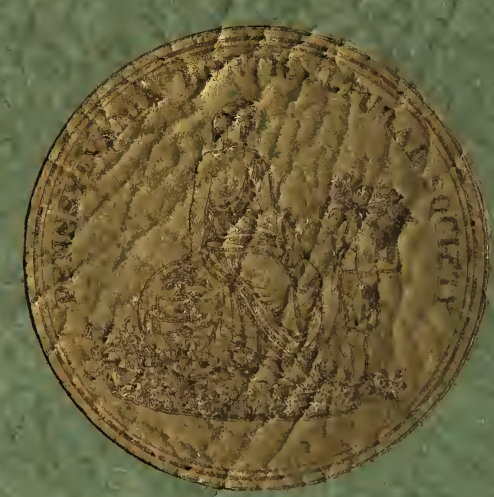

1924

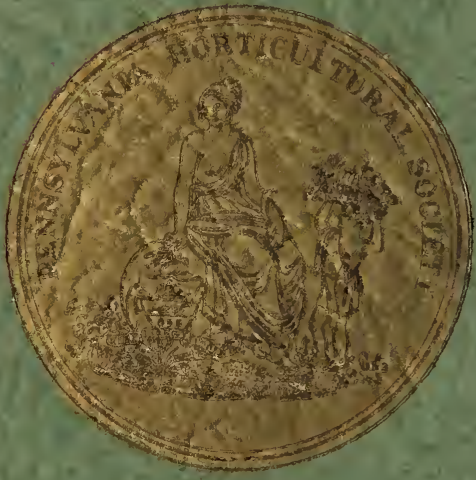

\section{5}

1926

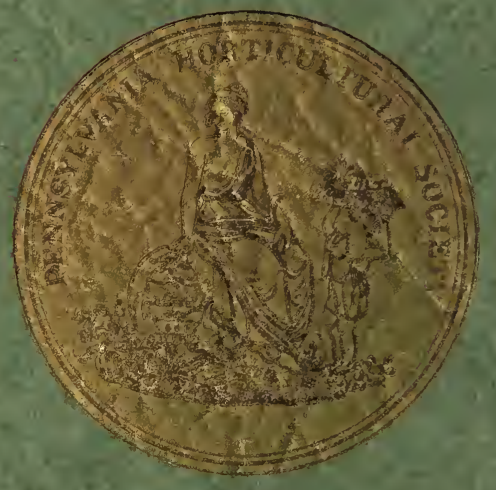

1927

1928 